\title{
Are We Seeing Dematerialization of World GDP?
}

\author{
Rögnvaldur Hannesson ${ }^{1}$
}

Received: 22 December 2020 / Revised: 22 December 2020 / Accepted: 28 April 2021 / Published online: 11 May 2021

(c) The Author(s) 2021

\begin{abstract}
Production of commodities and industrial products typically declines in relative terms as countries get richer. Does this mean that economic growth will become dematerialized and take place without being accompanied by a rise in the use of materials? Do we see signs of this already happening? We look at the production of cement and thirteen minerals 1960-2019 and find no evidence of dematerialization. Production of cement and eight minerals has grown more rapidly than world GDP and that of three minerals more rapidly than world population. Extraction of most minerals has accelerated rather than stagnated since the turn of the century.
\end{abstract}

Keywords Mineral production $\cdot$ GDP $\cdot$ Economic growth $\cdot$ Dematerialization

JEL Classification N50 $\cdot \mathrm{O} 13 \cdot \mathrm{Q} 32$

\section{Introduction}

Dematerialization has for some time been a hot topic in the academic literature on economic growth and environmental economics. Dematerialization means that economies use less and less of materials (minerals, energy carriers, biomass, etc.) per unit of real GDP as time passes, making economic growth possible without increasing the use of materials with the associated environmental effects.

How far can dematerialization of GDP be pushed? Some economists take a sanguine view:

A central question of environmental policy is whether it will be possible to reach an absolute decoupling of economic growth measured in monetary terms at constant prices from the extraction of natural resources measured in physical units. (Meyer et al. 2012, p. 145).

Were this to happen, our material needs would have to be already satisfied, so that further economic growth would all be about immaterial things. In a world where the population is still growing and millions of people are still living in poverty, we seem to be far from such "absolute decoupling." It

Rögnvaldur Hannesson

Rognvaldur.hannesson@nhh.no

1 Professor Emeritus, Norwegian School of Economics, Bergen, Norway bears pointing out that even if the material intensity of GDP is declining, our use of material might still go up because of the "scale effect" of economic growth.

Dematerialization is usually thought of as being the consequence of expansion of the services sector together with a stagnation or contraction of the industrial sector. While it is true that the services sector is less material-intensive than the industrial sector, it is less clear whether the services sector can expand independently of the industrial sector. Some analysts (e.g., Jespersen 1999) see the services sector as complementary to the industrial sector; neither can exist entirely on its own and without the other. Recently, Fix (2019) has called into question the hypothesis of dematerialization driven by the expansion of services and concluded that this is not true for energy in particular. He also provides a good, if condensed, general introduction to the issue.

The purpose of this paper is analytically modest, but nevertheless important. I examine what has happened to the production of cement and thirteen important industrial minerals since 1960. Has it grown less than GDP? Has it grown less than world population? Has it grown less rapidly, or perhaps declined, since the turn of the century? If the world economy is in fact dematerializing, the use of minerals would not only have to grow more slowly than GDP and world population but decline in absolute terms. I look at this for the world as a whole. It is well known that the share of minerals and industrial production in GDP (gross 
domestic product) declines as countries get richer (Radetzki and Wårell 2017; Humphreys 2013). Looking at the material content of GDP in rich countries may, however, exaggerate the possibilities of "dematerialization" of GDP for the world as a whole, because rich countries have outsourced their industrial production and even extraction of minerals to the so-called developing countries. ${ }^{1}$ Energy carriers (coal, oil, natural gas) are not a part of this investigation, and neither is production of food such as meats, fish or plant products. These materials are, of course, a part of the whole picture of material use.

Looking specifically at the extraction of minerals is important not only on its own but also because digging up minerals and converting them into useful products is energy-intensive. Since the world economy is still critically dependent on fossil fuels, this has implications for reducing carbon dioxide emissions. Unless extraction and processing of minerals could be based on using energy from renewable resources in the near future, further extraction will continue to contribute to emissions of greenhouse gases, especially carbon dioxide.

What should we expect? If the material needs of humanity were already well satisfied, there would be little need for more mineral extraction per capita, implying that mineral extraction would grow at a rate similar to world population. Given that millions of people still live in poverty, alleviation of this would necessitate a more rapid growth of mineral extraction. But given also that the material intensity of GDP has been falling in rich countries, mineral extraction would grow more slowly than GDP in these countries. Would it, therefore, grow more slowly than world GDP? Not necessarily; if the needs of poor and medium rich countries are being satisfied sufficiently quickly, we could witness growth rates of mineral extraction in excess of world GDP.

\section{The Data}

The data cover the period 1960-2019. Data on mineral extraction and cement production are from the US Geological Survey while data on world population and GDP are from the World Bank, with GDP expressed in US dollars at 2010 prices. The minerals I examine are bauxite, copper, cobalt, iron ore, lead, lithium, magnesium, molybdenum, nickel, the platinum group, rare earths, tin and zinc. Of these, iron ore is the most bulky and in our minds probably the one most closely associated with industrialization,

\footnotetext{
${ }^{1}$ Helm (2012) discusses outsourcing of $\mathrm{CO}_{2}$-intensive production to developing countries and shows how a decrease in $\mathrm{CO}_{2}$ emissions for the UK turn into an increase if one accounts for emissions on basis of consumption rather than production.
}

Table 1 Production of thirteen minerals and cement 2015-2019 (average per year)

\begin{tabular}{ll}
\hline Mineral & Tonnes \\
\hline Cement & $4.07 \mathrm{E}+09$ \\
Iron ore & $2.41 \mathrm{E}+09$ \\
Bauxite & $3.16 \mathrm{E}+08$ \\
Copper & $1.99 \mathrm{E}+07$ \\
Zinc & $1.28 \mathrm{E}+07$ \\
Lead & $4.66 \mathrm{E}+06$ \\
Nickel & $2.33 \mathrm{E}+06$ \\
Magnesium & $1.02 \mathrm{E}+06$ \\
Tin & $3.14 \mathrm{E}+05$ \\
Molybdenum & $2.90 \mathrm{E}+05$ \\
Rare earths & $1.59 \mathrm{E}+05$ \\
Cobalt & $1.27 \mathrm{E}+05$ \\
Lithium & $6.23 \mathrm{E}+04$ \\
Platinum group & $4.65 \mathrm{E}+02$ \\
\hline
\end{tabular}

while minerals such as magnesium, molybdenum, nickel and platinum are used in industrial processes and blended in with iron to produce steel of specific qualities. Bauxite is the raw material for aluminum, which we find in a variety of uses. I leave out precious minerals (gold and silver), which are not closely related to industrialization, and some minor minerals used in industrial processes and steel alloys (vanadium, for example).

Table 1 shows the production per year of the thirteen minerals and cement 2015-2019. The numbers are in scientific format, which makes for an easy comparison in terms of quantity. The basic unit is tonnes. Cement tops the list, with the annual production amounting to billions of tonnes. Iron ore is not far behind, also produced in billions of tonnes each year. Bauxite is produced in hundreds of millions of tonnes, copper and zinc in tens of millions of tonnes, and so on down to the platinum group, which is measured in hundreds of tonnes. The platinum group consists of six metals: platinum, palladium, iridium, osmium, rhodium and ruthenium. Platinum and palladium account for most of the quantity produced.

The quantity produced of these thirteen minerals and cement is not necessarily proportional to their environmental disruption. The production of cement requires mining of a large amount of limestone or other sources of calcium, and its use requires roughly six times the amount of sand and gravel. Production of mineral ores requires digging up a large amount of dirt, from which the ore must be extracted. The ore must be further refined to be useable, and the refining requires substantial use of energy and chemicals which typically are harmful for the environment. Even small amounts of metal can require digging up substantial amounts of dirt. Mills (2020) provides an example of a halftonne electric-car battery containing lithium, cobalt, nickel, 
graphite, copper, steel and aluminum, requiring digging up 100-700 tonnes of dirt.

\section{Results}

Figure 1 and Table 2 compare the developments in extraction of the aforementioned thirteen minerals and cement production with the development of GDP and world population. There is not much support for the hypothesis that the world economy is dematerializing. The extraction of six minerals (bauxite, the platinum group, magnesium, cobalt, molybdenum and nickel) and the production of cement grew faster than GDP from 1960 to 2019. Two minerals, lithium and rare earths, are newcomers to the scene; for these we have first observations from 1975 and 1985. Extraction of lithium has grown by more than $9 \%$ per year, way ahead of GDP. Extraction of rare earths has also grown faster than GDP over the period $1987-2017$, or by $3.8 \%$ per year compared with $2.9 \%$ for GDP. Lithium and rare earths are minerals associated in particular with the IT-revolution, being used in batteries for electric cars, smartphones and various IT-gadgets. This revolution has certainly had its own idiosyncratic dependence on materials. Cobalt and nickel are used in batteries, so their increasing use is also related to the development of the digital age.

Extraction of three minerals (copper, iron ore and zinc) has grown more slowly than GDP, but faster than world population. Extraction of two minerals, tin and lead, has grown more slowly than world population, but grown nevertheless.

A conspicuous feature of Fig. 1 is that the extraction of most minerals began to grow more quickly in the late 1990s or early 2000s. For cobalt and copper this happened in the mid-1990s, but for bauxite, magnesium, molybdenum and zinc a little later (around or just after 2000). The latter is also true for cement, which, however, has tapered off lately. It is tempting to see this increase as a result of the rapid economic growth in China and some other poor countries from the 1990s onwards.For iron ore, aluminum and copper we have particularly clear evidence. The production of iron ore took a sudden leap upwards 2002-2009, but has had a relatively stable growth after that. China's imports of iron ore rose from 70 million tonnes in 2000 to 620 in 2010, which coincided with a doubling of world production of iron ore (Hellmer and Ekstrand 2013). China's share of global demand growth 2005-2013 was 85\% for aluminum and $130 \%$ for copper (Radetzki and Wårell 2017, p. 51). China's industrialization has also left its indelible mark on time series of energy carriers (coal, oil) and emissions of carbon dioxide.

It is noteworthy that the growth rate of cement production and extraction of most minerals was higher in the period 1995-1999 to 2015-2019 than over the whole period
1960/64-2015/19, with two exceptions (rare earths and the platinum group), as shown in Table 2. Dematerialization is often seen as a result of the "second machine age" characterized by the use of computers and other electronic equipment (McAfee 2019). Exactly when the second machine age began is not easy to determine. McAfee (op. cit.) shows that the consumption of five metals (aluminum, nickel, copper, steel and gold) has declined in the United States since about 2000, so dating the beginning of the second machine age to 1995-1999 is not a bad approximation. Nevertheless, the growth in the use of minerals and cement was higher after the turn of the century than from the early 1960s to the turn of the century. The extraction of all thirteen minerals grew faster than population after the turn of the century, but four grew more slowly than GDP.

Is this a definitive refutation of the dematerialization hypothesis? McAfee (op. cit.) attributes dematerialization to GDP becoming less material-intensive, implying that future growth could take place without increasing the use of materials. I have just shown that the GDP for the world as a whole has not become less material-intensive as far as cement and most minerals are concerned. One interpretation is that most countries in the world have not yet reached a level of development comparable to that of the United States and other longsince industrialized countries, so that it is simply too early to expect seeing dematerialization occurring for the world as a whole.

There is, however, another and more plausible interpretation. The reason why we are seeing a dematerialization of the US economy, and the economies of other industrially advanced countries for that matter, is that these economies have outsourced the production of material-intensive goods to developing countries such as China, and not that these countries' economies are dematerializing. This is not easy to verify; it is not enough to look at imports of ores and metals, much of such imports is embodied in finished industrial products that are increasingly being imported to industrially advanced countries. But the world as a whole cannot outsource anything. Dematerialization is not happening for the world as a whole, and the reason likely is that the economies of industrially advanced countries are probably as material-intensive as ever, they are just importing their most material-intensive goods from elsewhere. Another reason why dematerialization with respect to minerals seems to be happening in industrially advanced countries is substitution of plastics for minerals, a question worthy of looking into on its own. Such substitution does not amount to dematerialization however. 


\section{Bauxite}

1500

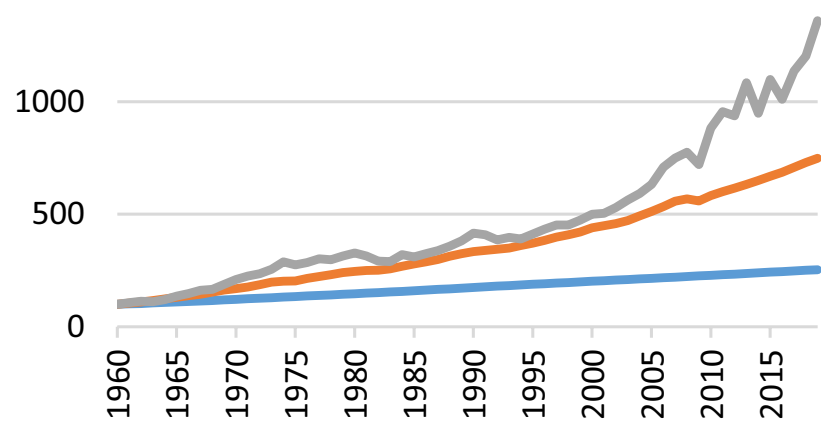

$\Longrightarrow$ Population $=$ GDP Bauxite

\section{Cobalt}

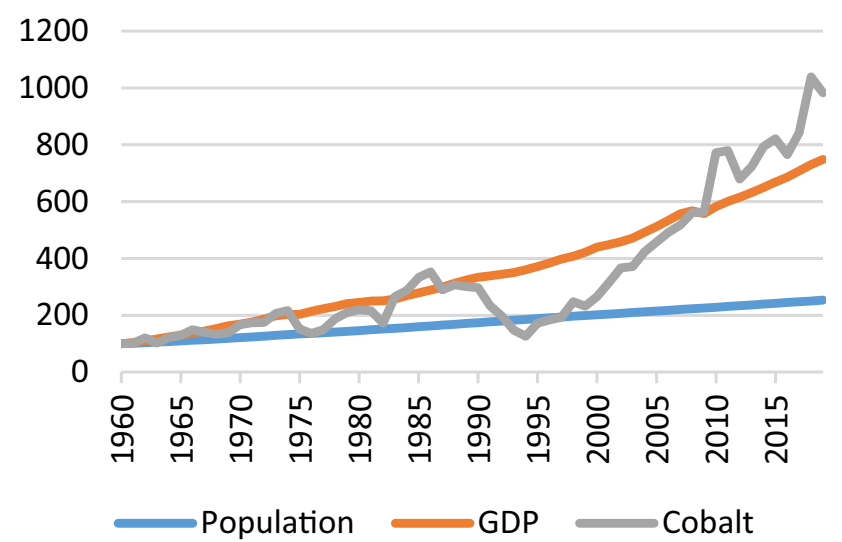

Iron ore

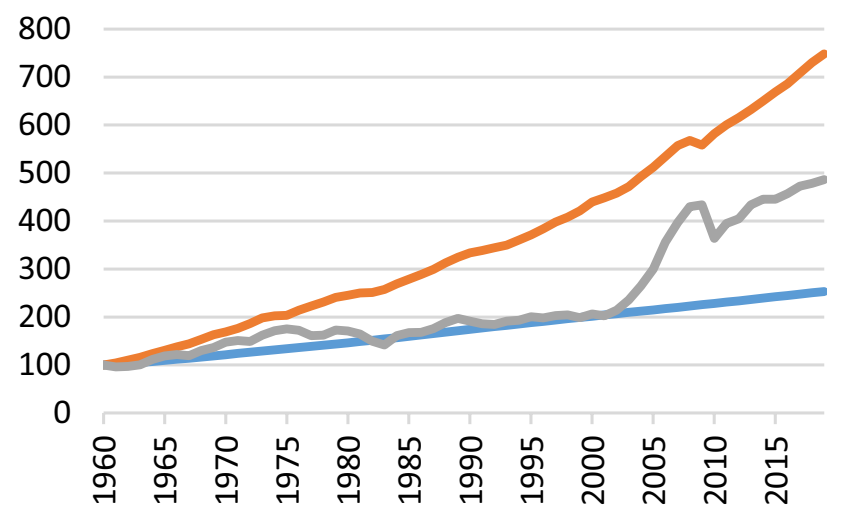

$\longrightarrow$ Population GDP Iron ore

\section{Cement}

1400
1200
1000
800
600
400
200
0

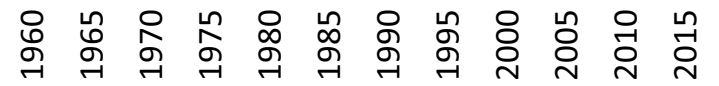

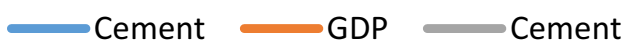

\section{Copper}

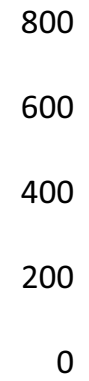

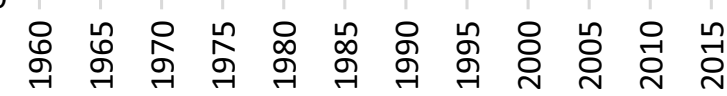

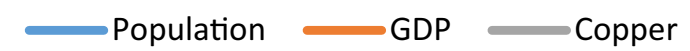

\section{Lead}

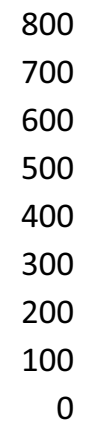

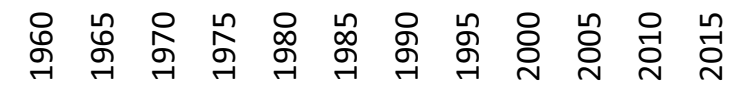

$\longrightarrow$ Population GDP Lead

Fig. 1 Production of thirteen minerals and cement, world population and world GDP. Index numbers 
Lithium

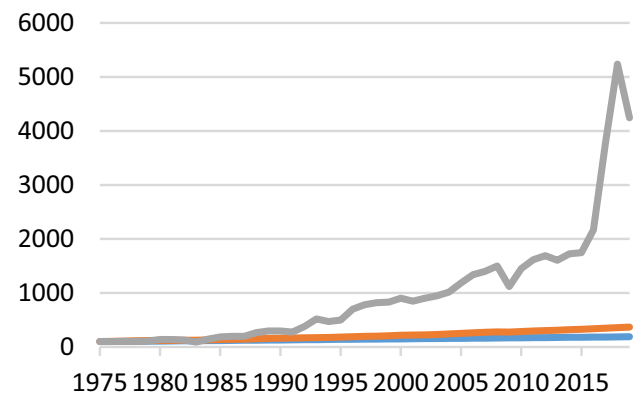

Population GDP Lithium

\section{Molybdenum}

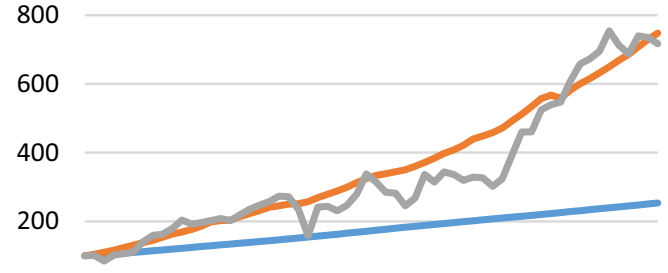

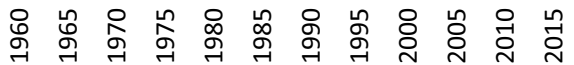

Population GDP Molybdenum

\section{Platinum group}

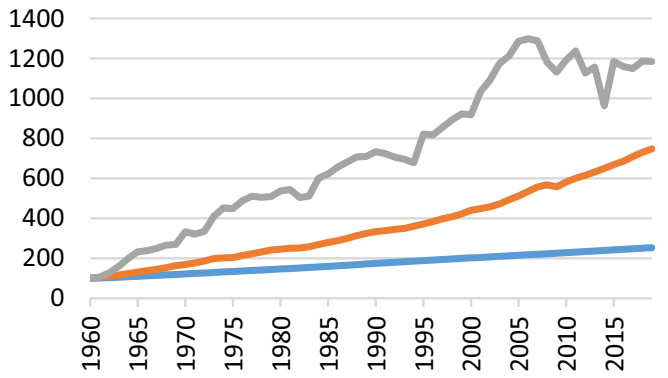

Population GDP Platinum

\section{Zinc}

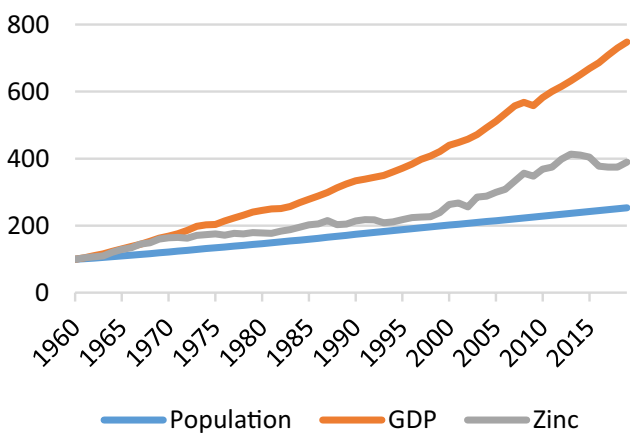

\section{Magnesium}

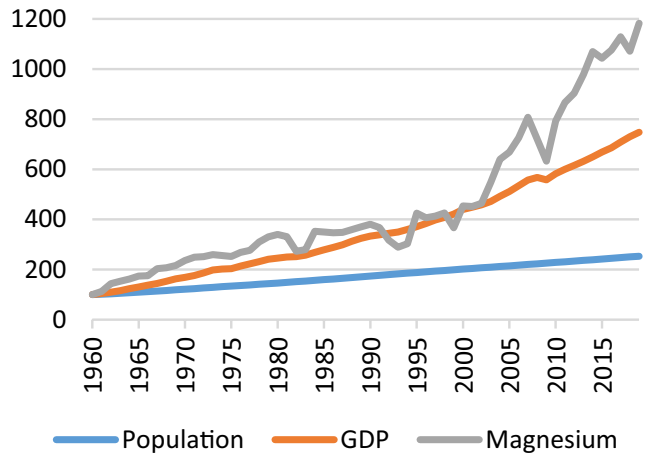

Nickel

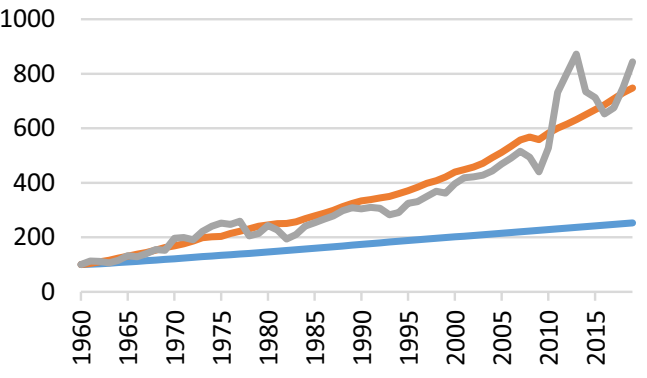

$\longrightarrow$ Population GDP Nickel

Rare earths

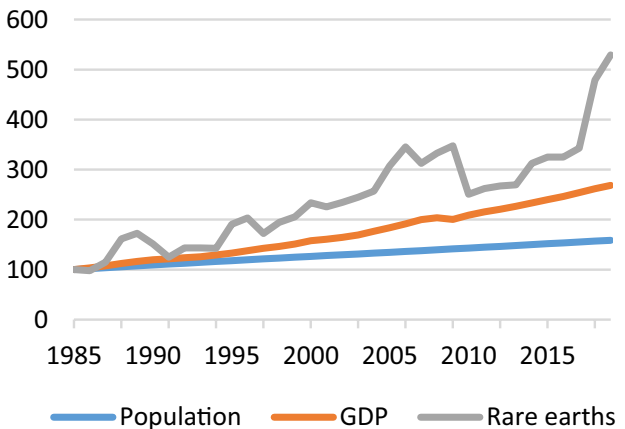

Tin

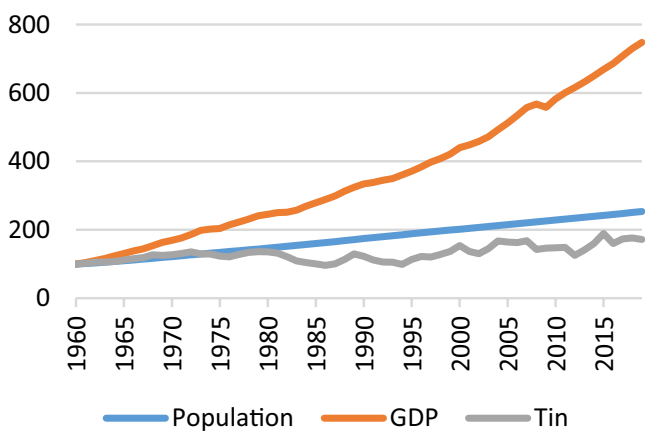

Fig. 1 (continued) 
Table 2 Annualized growth rates of production of minerals and cement from the early 1960 s to the late 2010 s versus late 1990 s to late $2010 \mathrm{~s}$

\begin{tabular}{llll}
\hline $\begin{array}{l}\text { Annualized growth 1960/64- } \\
\text { 2015/19 }\end{array}$ & \multicolumn{2}{l}{ Annualized growth 1995/99- } \\
\hline Lithium & $9.2 \%$ & Lithium & $8.1 \%$ \\
Cement & $4.5 \%$ & Cobalt & $7.6 \%$ \\
Bauxite & $4.4 \%$ & Magnesium & $5.1 \%$ \\
Platinum group & $4.0 \%$ & Cement & $5.0 \%$ \\
Magnesium & $3.9 \%$ & Bauxite & $4.9 \%$ \\
Cobalt & $3.9 \%$ & Iron ore & $4.3 \%$ \\
Rare earths & $3.8 \%$ & Molybdenum & $4.0 \%$ \\
Molybdenum & $3.7 \%$ & Nickel & $3.8 \%$ \\
Nickel & $3.5 \%$ & Rare earths & $3.7 \%$ \\
GDP & $3.5 \%$ & GDP & $3.1 \%$ \\
Iron ore & $2.8 \%$ & Copper & $2.8 \%$ \\
Copper & $2.7 \%$ & Zinc & $2.7 \%$ \\
Zinc & $2.3 \%$ & Lead & $2.2 \%$ \\
Population & $1.6 \%$ & Tin & $1.7 \%$ \\
Lead & $1.2 \%$ & Platinum group & $1.6 \%$ \\
Tin & $0.9 \%$ & Population & $1.3 \%$ \\
\hline
\end{tabular}

For lithium the first base period is annual average 1975-1979 and for rare earths it is 1985-1989. The US is not included in the production of lithium. For population and GDP at constant prices we use single base and end years (1960, 1997 and 2019)

\section{Conclusion}

The development in mineral extraction and cement production since 1960 shows few signs of dematerialization of world GDP. The production of eleven out of thirteen minerals important for industrial production has grown faster than world population, and eight have grown faster than world GDP. Rather than decline, the growth in extraction of most minerals accelerated from the 1990s onwards. Mineral production is unlikely to become stabilized in the near future, provided that abatement of poverty in the world will continue. Dematerialization seems to be a myth, nourished by the fact that rich countries have outsourced much of their industrial production to developing countries. Looking at the world as a whole there is no evidence whatever of dematerialization in the extraction of minerals and use of cement.
Funding Open access funding provided by Norwegian School Of Economics.

\section{Declarations}

Conflict of interest The author declares that he has no conflict of interest.

Open Access This article is licensed under a Creative Commons Attribution 4.0 International License, which permits use, sharing, adaptation, distribution and reproduction in any medium or format, as long as you give appropriate credit to the original author(s) and the source, provide a link to the Creative Commons licence, and indicate if changes were made. The images or other third party material in this article are included in the article's Creative Commons licence, unless indicated otherwise in a credit line to the material. If material is not included in the article's Creative Commons licence and your intended use is not permitted by statutory regulation or exceeds the permitted use, you will need to obtain permission directly from the copyright holder. To view a copy of this licence, visit http://creativecommons.org/licenses/by/4.0/.

\section{References}

Fix B (2019) Dematerialization through services: evaluating the evidence. Biophys Econ Resour Qual 4:6

Hellmer S, Ekstrand J (2013) The iron ore world market in the early twenty-first century - the impact of the increasing Chinese dominance. Miner Econ 25:89-95

Helm D (2012) The carbon crunch. Yale University Press, New Haven Humphreys D (2013) Long-run availability of mineral commodities. Miner Econ 26:1-11

Jespersen J (1999) Reconciling environment and employment by switching from goods to services? A review of Danish experience. Eur Environ 9:17-23

McAfee A (2019) More from less. Scribner, New York

Meyer B, Meyer M, Distelkamp M (2012) Modeling green growth and resource efficiency: new results. Miner Econ 24:145-154

Mills MP (2020) Mines, minerals and "green energy": a reality check. Report July 2020. The Manhattan Institute

Radetzki M, Wårell L (2017) A handbook of primary commodities in the global economy. Cambridge University Press

Publisher's Note Springer Nature remains neutral with regard to jurisdictional claims in published maps and institutional affiliations. 